\title{
PODMIOT JAKO WEWNĘTRZNY BIEGUN SYMBOLIZMU. ANTYMENTALISTYCZNA WYKŁADNIA TRAKTATU LOGICZNO-FILOZOFICZNEGO
}

Słowa kluczowe: Ludwig Wittgenstein, Tractatus logico-philosophicus, antyrealizm, antymentalizm, podmiot transcendentalny, symbolizm

Keywords: Ludwig Wittgenstein, Tractatus logico-philosophicus, anti-realism, antimentalism, transcendental subject, symbolism

Tractatus logico-philosophicus zawiera niewątpliwie pewną wizję języka i logiki. Czy zawiera również pewną filozofię umysłu? Na to pytanie będę starał się odpowiedzieć, umieszczając je przede wszystkim w kontekście rozważań dotyczących związku języka z rzeczywistością. W niniejszym artykule broniona i rozwijana będzie antyrealistyczna, a w konsekwencji również antymentalistyczna wykładnia filozofii wczesnego Wittgensteina proponowana przez Corę Diamond, Daniela Hutto i Marie McGinn. Wedle tej

* Jakub Gomułka - dr, adiunkt Katedry Filozofii Boga Wydziału Filozoficznego Uniwersytetu Papieskiego Jana Pawła II w Krakowie. Zajmuje się filozofią religii, języka i umysłu, a także filozofią Ludwiga Wittgensteina. Wydał monografię Gramatyka wiary. Dziedzictwo Wittgensteinowskiego fideizmu (Kraków 2011).

Address for correspondence: Jakub Gomułka, PhD, Assistant Professor at the Chair of Philosophy of God, the Philosophical Faculty of the Pontifical University of John Paul II in Cracow. Postal address: Sekretariat Wydziału Filozoficznego UP JPII, ul. Kanonicza 9, 31-002 Kraków. E-mail: jakub.gomulka@upjp2.edu.pl. 
wykładni początkowe tezy Traktatu nie mówią o świecie, lecz stanowią część objaśnień dotyczących natury symbolizmu, podobnie jak uwagi dotyczące projekcji sensu nie odnoszą się do operacji umysłowych, lecz do wewnętrznej struktury symbolu. Oznacza to, że przypisywana Wittgensteinowi ontologia rzeczy i faktów jest owocem niezrozumienia jego intencji, co objawia się ignorowaniem treści autotematycznej tezy $6.54^{1}$ i grupy tez 4.111-4.115, mówiących o tym, czym jest filozofia. Oznacza to również, że na zagadnienie roli podmiotu w Traktacie, a w szczególności na kwestię podmiotu metafizycznego, należy patrzeć z perspektywy koncepcji symbolizmu.

Co oznacza tytułowe stwierdzenie, że podmiot jest wewnętrznym biegunem symbolizmu? Jak zobaczymy, oznacza ono przyjęcie tezy, wedle której konieczna struktura języka zawiera w sobie wszystkie warunki sensowności zdań, i uznanie, że faktyczne podmioty nie konstytuują sensu symbolu, lecz same od niego zależą. Prezentację tej wykładni rozpoczniemy od wskazania, że jest ona przedłużeniem antyrealistycznych interpretacji, odmawiających tezom Traktatu statusu zdań opisowych i uznających je za objaśnienia. Następnie przedstawimy wspierającą antyrealizm krytykę mentalizmu, rozwijaną na podstawie tezy 5.542. Dalej wskazana zostanie możliwość antyrealistycznych odczytań uwag o projekcji. Prezentowaną interpretację wesprze również analiza wątku solipsyzmu z tez 5.6-5.641. Na koniec wskazane zostanie możliwe źródło i motywacja „upodmiotowienia” symbolizmu przez wczesnego Wittgensteina.

W ciągu niemal wieku, jaki upłynął od publikacji Traktatu, zaproponowano jego wiele różnorodnych interpretacji. Do najbardziej znanych klasycznych pozycji w tym zakresie należą m.in.: An Introduction to Wittgenstein's Tractatus Gertrude Anscombe (1965), Wittgenstein's Tractatus Erika Steniusa (1960), A Companion to Wittgenstein's Tractatus Maksa Blacka (1964), Insight and Illusion Petera Hackera (1972) czy The False Prison Davida Pearsa (1987). Mimo licznych różnic między tymi propozycjami z dzisiejszej

\footnotetext{
1 W odwołaniach do Traktatu stosuję powszechnie przyjętą konwencję podawania numeru tezy, a nie strony (wyjątkiem jest Przedmowa). W związku z tym pomijam formalne odsyłacze wszędzie tam, gdzie numer tezy podany jest w tekście. Dodatkowo formę odsyłacza „Wittgenstein 1997” zastępuję skrótem „TLP”.
} 
perspektywy podkreśla się zwykle to, co je łączy, a mianowicie zasadniczo podobny sposób ujęcia zagadnienia statusu treści Traktatu. Wszyscy wymienieni autorzy zakładają bowiem, że książka ta stanowi prezentację pewnego mniej lub bardziej spójnego zespołu teorii filozoficznych dotyczących świata, języka i logiki, które tłumaczą, jak to się dzieje, że wyrażenia językowe mają sens. Celem Traktatu ma więc być teoretyczna eksplikacja relacji języka do rzeczywistości, przy czym wykład fundamentalnej struktury owej rzeczywistości, który zawierać mają początkowe, tzw. ontologiczne, tezy dzieła, ujmowany jest bądź w kategoriach metafizyki realistycznej, bądź transcendentalizmu². Pochodną takiego ujęcia wczesnej filozofii Wittgensteina jest podkreślanie radykalizmu zmiany, jaka dokonała się w jego myśli na początku lat trzydziestych.

Najpoważniejszym problemem klasycznych interpretacji Traktatu była jego samowywrotność. Wiele ważnych tez tego dzieła - Hacker (2009, s. 409-411) prezentuje ich obszerny katalog - nie może być uznanych za zdania sensowne wedle kryteriów, które ono samo prezentuje. Co więcej, uwagi w tezach 4.111-4.116 mówią, że filozofia nie jest teorią, nie przedstawia żadnych tez, jest natomiast działalnością polegającą na rozjaśnianiu naszych myśli. Największą zagadkę stanowi z punktu widzenia klasycznych interpretacji teza 6.54, która stwierdza:

Tezy moje wnoszą jasność przez to, że kto mnie rozumie, rozpozna je w końcu jako niedorzeczne; gdy przez nie - po nich - wyjdzie ponad nie. (Musi niejako odrzucić drabinę, uprzednio się po niej wspiąwszy).

Musi te tezy przezwyciężyć, wtedy świat przedstawi mu się właściwie.

Skonfrontowani z tymi uwagami zwolennicy odczytywania Traktatu jako dzieła zawierającego pewne teorie filozoficzne odpowiadali, że najwyraźniej wedle intencji wczesnego Wittgensteina istnieją pewne nie-

2 Modelowy przykład realistycznego odczytania znajdziemy u Pearsa (1987, s. 8): ,[...] Tractatus jest fundamentalnie realistyczny w tym sensie, że język cechuje się pewną dowolnością w warstwie powierzchniowej, lecz w głębi ugruntowany jest on na koniecznej naturze przedmiotów, która nie jest naszym dziełem, lecz jest nam przeciwstawiona w tajemniczej niezależności”. W kwestii odczytania transcendentalnego zob. przypis 18 . 
wyrażalne prawdy, które można jedynie pokazać, i to właśnie czynią jego niedorzeczne tezy ${ }^{3}$.

Konsensus w kwestii traktowania wczesnej filozofii Wittgensteina jako teorii relacji języka i świata nie był nigdy zupełny. Podważała go m.in. Hidé Ishiguro (1969), a także Rush Rhees (1970), jeden z trojga wykonawców testamentu autora Traktatu i opiekunów jego spuścizny. Jednak zasadnicza zmiana klimatu wokół fílozofii wczesnego Wittgensteina nadeszła dopiero pod koniec wieku XX. Jej zapowiedzią były teksty Cory Diamond (1988, 1991) i Jamesa Conanta (1992), a kulminacją wydanie w roku 2000 monografii zbiorowej pod znamiennym tytułem The New Wittgenstein ${ }^{4}$, której autorzy (oprócz Cory Diamond i Jamesa Conanta także m.in. Juliet Floyd i Hilary Putnam) podważyli tezę o radykalnej różnicy dzielącej wczesną i późną filozofię autora Traktatu i zaprezentowali „terapeutyczne” ujęcie tego ostatniego dzieła. Opierało się ono na tezie, że Wittgenstein - na podstawie pewnych zarodkowych idei Fregego - wypracował tzw. zdecydowaną (resolute) koncepcję niedorzeczności, wedle której o braku sensu naszych wypowiedzi decyduje to, że pewnym znakom nie nadaliśmy znaczenia (TLP, 5.4733); oznacza to, że nie może być mowy o żadnych niewyrażalnych prawdach, a niedorzeczności pokazują tylko to, że są niedorzecznościami. W świetle tych założeń Traktat nie może być traktowany jak typowa książka filozoficzna - jest raczej rodzajem ,ścieżki zdrowia” dla metafizyka, gdyż tylko udaje, że prezentuje jakieś tezy, by pod koniec lektury uzmysłowić czytelnikowi, że jego wstępne przekonanie, iż można te tezy zrozumieć, było złudzeniem (Diamond, 2009, s. 183).

W świetle wykładni „zdecydowanej” stwierdzenie, że wczesny Wittgenstein nie prezentował żadnej teorii umysłu, jest oczywiście trywialne. Wydaje się jednak, że radykalizm tej interpretacji idzie zbyt daleko. Jak obszernie argumentuje Hacker (2009, s. 430-442), nie da się jej pogodzić z licznymi zachowanymi wypowiedziami autora Traktatu, w których Wittgenstein traktuje tezy swojego dzieła jak najbardziej poważnie, broniąc ich bądź je krytykując. Czy jednak, jeśli odrzucimy odczytanie „zdecydowane”, musimy uznać, że pisząc swoją pierwszą książkę, filozof był przekonany o istnieniu niewyrażalnych prawd?

3 Jak wskazuje Warren Goldfarb (2011, s. 6), w sposób najbardziej jednoznaczny odpowiedzi takiej udzielali David Pears i Peter Hacker.

4 Monografia ta została wydana również po polsku: Crary, Read, 2009. 
Na tak sformułowane pytanie negatywnej odpowiedzi udzielają Daniel Hutto (2004), Marie McGinn (1999, 2006), Danièle Moyal-Sharrock (2007) czy wspomniana Cory Diamond w swoich późniejszych tekstach (np. Diamond, 2006) $)^{5}$. Podobnie jak interpretatorzy „,zdecydowani”, uznają oni ideę niewyrażalnych prawd za podejrzaną i sprzeczną z wieloma jednoznacznymi deklaracjami autora Traktatu (Hutto, 2004, s. 90-92). Z drugiej jednak strony nie dezawuują tez Wittgensteina jako „zwykłych” niedorzeczności, zwracają bowiem uwagę, że jako takie nie mogłyby one pełnić funkcji szczebli drabiny, po której mielibyśmy się wspinać (McGinn, 1999, s. 496). Zamiast tego proponują uznanie tez Traktatu - zgodnie z sugestią wyrażoną w 4.112 i 6.54 - za objaśnienia wnoszące jasność w nasze myśli. Objaśnienia te niczego nie mówią, nie można za ich pomocą stworzyć żadnej teorii, ponieważ nie pełnią one funkcji zdań sensownych - nie obrazują żadnych stanów rzeczy - lecz stanowią zbiór dyrektyw porządkowania notacji ukazujących związki między wyrażeniami. Związki te nie są dla nas zresztą niczym nowym - objaśnienia uprzytomniają nam to, co już wiemy jako użytkownicy języka (Hutto, 2004, s. 99) ${ }^{6}$. Zatem, przykładowo, intencją stojącą za tezą 3, która głosi, że logicznym obrazem faktów jest myśl, nie było rozwijanie pewnej teorii związku między myślą a rzeczywistością, lecz wskazanie, że wyrażenia „logiczny obraz faktów” i „myśl” są wzajemnie zastępowalne ${ }^{7}$.

Przedstawiciele trzeciego nurtu interpretacyjnego, podobnie jak zwolennicy wykładni „zdecydowanej”, sprzeciwiają się twierdzeniu, jakoby Traktat zawierał jakąkolwiek ontologię. Tezy o numerach 1.x, 2.x i 3.x odczytują oni bowiem jako objaśnienia wskazujące na różnicę między treścią, strukturą - czyli układem treści - i konieczną formą, która wyznacza granice wszelkim możliwym strukturom symbolicznym (McGinn, 1999, s. 500). Interpretacje Traktatu jako zbioru objaśnień są zatem antyrealistyczne. Jak wykażemy, prowadzą one również do antymentalistycznych wniosków.

\footnotetext{
5 W Polsce odczytanie to popularyzuje Piotr Dehnel (2014).

6 Jest to więc odmienna od klasycznej interpretacja natury objaśnień. Według Maksa Blacka (1964, s. 114 i n.) traktatowe objaśnienia są bowiem zdaniami. Podobnie sądzi Peter Hacker (1972, s. 50), który dodaje, że objaśnienia funkcjonują w Traktacie jako definicje ostensywne, a zatem służą wprowadzeniu do języka nowych znaków odnoszących się bezpośrednio do elementów pozajęzykowych.

7 Eksplikuję to ujęcie tez Traktatu, inspirując się nieopublikowanym tekstem Jana Wawrzyniaka pt. How to Understand die Sätze of Tractatus?
} 
Realistyczne interpretacje fillozofii wczesnego Wittgensteina pociągają za sobą mentalistyczne odczytanie relacji między językiem a rzeczywistością. W Traktacie czytamy, że zdanie sensowne, czyli myśl (TLP, 4), mówi o fakcie dzięki temu, że jest jego obrazem logicznym (TLP, 3), a więc że odwzorowuje go dzięki wspólnej formie odwzorowania (TLP, 2.17) i przyporządkowaniu zachodzącemu między elementami obrazu a przedmiotami (TLP, 2.1514). Owo przyporządkowanie możliwe jest dzięki projekcji, której metodą jest pomyślenie sensu zdania (TLP, 3.11). Jeśli więc przedmioty istnieją niezależnie i uprzednio względem wyrażeń językowych, to pomyślenie sensu zdania musi być rozumiane jako akt umysłu istniejącego również niezależnie i uprzednio względem języka. Umysł odpowiadałby bowiem za nadawanie sensu zdaniom. Ten wniosek pozwala zwolennikom wykładni realistycznych stawiać pytanie o różnicę między językiem a myśleniem i mówić o „myślowych procesach analizy przeprowadzanych przez nas bądź w nas zachodzących" (Malcolm, 1994, s. 53), a także o hipotetycznym procesie psychologicznym, który nadaje semantyczny wymiar znakom (Hacker, 1972, s. 47) ${ }^{8}$.

Trudno jednak z takimi wykładniami pogodzić uwagi Wittgensteina dotyczące zdań pozornie (jego zdaniem) nieekstensjonalnych. W tezach 5.541-5.5423 prezentuje on krytykę ,nowoczesnych teorii poznania”, w których podmiot myślący stanowił człon relacji ze zdaniem, a właściwie - jak w wieloargumentowej relacyjnej teorii sądzenia Russella9 ${ }^{9}$ o którą tu przede wszystkim chodzi - z elementami zdania. W tezie 5.542 Wittgenstein pisze:

Jest jednak jasne, że zwroty , $A$ sądzi, że $p ”, ~, A$ myśli $p ”, ~, A$ mówi $p "$ mają formę „ " $p$ ' mówi $p$ ". A tutaj nie mamy przyporządkowania faktu przedmiotowi, lecz przyporządkowanie faktów przez przyporządkowanie sobie ich przedmiotów.

Teoria Russella zakładała, że podmiot dokonujący sądu jest czymś zewnętrznym względem języka (co wydawało się oczywiste), a przy tym jest elementem nierozkładalnym, nadającym wyrażeniom jedność przez łączenie

8 Poza Normanem Malcolmem i Peterem Hackerem odczytanie mentalistyczne proponują również m.in.: David Stern (1995, s. 69), a w Polsce np. Wiesław Walentukiewicz (1998) czy Włodzimierz Heflik (2013, s. 292 i n.).

9 Polskie tłumaczenie nazwy teorii Russella podaję za Dehnelem (2014, s. 210). 
je w zdanie. Wittgenstein odrzucił rozwiązanie autora The Principles of Mathematics, wskazując, że pozwala ono, aby przedmiotem sądzenia były konstrukcje nielogiczne i niegramatyczne (Potter, 2008, s. 121 i n.).

Traktatowe ujęcie sądzenia (przedstawione w tezie 5.542 i tezach ją komentujących) uwzględnia podmiot myślący, który nie jest ani prosty, ani pozajęzykowy. Jeśli „A myśli $p$ ” ma w rzeczywistości formę „ " $p$ ' myśli $p$ ”, to znaczy, że $A$ jest faktem symbolizującym fakt $p$, faktem, który jest związany z $p$ stosunkiem wewnętrznym, opartym na metodzie projekcji, dzięki któremu przedmioty wchodzące w skład ' $p$ ' są powiązane z przedmiotami wchodzącymi w skład $p$, jeśli $p$ zachodzi. W ten sposób okazuje się, że nieekstensjonalność zdań z czasownikami: „myśli”, „mówi”, „sądzi” itp. jest pozorna, co zabezpiecza tezę Wittgensteina, że wszystkie zdania są funkcjami prawdziwościowymi zdań elementarnych, która z kolei wynika z jego podstawowych założeń dotyczących logiki. Jednocześnie autor Traktatu pokazuje, że nie do utrzymania jest kartezjański w swej istocie model podmiotu myślącego jako gwaranta jedności sensu, który leży u podstaw teorii sądzenia i teorii poznania Russella (Sluga, 1996, s. 323-325; Dehnel, 2014, s. 212 i n. $)^{10}$.

W tym miejscu można jednak postawić pytanie: skoro opisywalny w języku Traktatu podmiot myślący jest pochodną metody projekcji, to kto lub co jest podmiotem aktu, jakim jest pomyślenie sensu zdania, zapewniającego wedle tezy 3.11 ową metodę? Odpowiedź na to pytanie eksplikuje zasadniczą tezę niniejszego artykułu, wedle której podmiot stanowi wewnętrzny biegun symbolizmu.

Należy przede wszystkim zauważyć, że - wbrew pozorom - 3.11 można odczytywać antymentalistycznie. Pierwsze takie odczytanie przedstawił Rush Rhees, który zaproponował, aby rozumieć tę tezę nie jako definicję

10 Może się wydawać, że teza 5.542 nie uprawnia do takiej interpretacji, ponieważ mowa jest w niej tylko o tym, w jaki sposób właściwie odczytywać pewną kategorię znaków zdaniowych. Na ten zarzut można odpowiedzieć, że Wittgenstein sam stosuje analogiczne uzasadnienie swojej tezy o nieistnieniu podmiotu myśli i wyobrażeń w tezie 5.632 (analizowanej dalej w tekście głównym). Można również odwołać się do uzasadnienia ogólniejszej natury: jeśli 5.542 odsłania właściwą strukturę symbolu , $A$ sądzi, że $p$ ", to ukazuje również strukturę naszych myśli. Innymi słowy, myśląc, że $A$ sądzi, że $p$, faktycznie myślimy, że ' $p$ ' sądzi, że $p$. Zarzut, że jest to „tylko” eksplikacja znaków zdaniowych, zawiera milczące założenie, że dysponujemy perspektywą zewnętrzną względem języka, a to - zdaniem autora Traktatu - nie jest prawdą. 
projekcji, lecz odwrotnie - jako definicję pomyślenia sensu wykorzystującą pojęcie projekcji, które zdaniem komentatora w pewien sposób zostało już objaśnione we wcześniejszych tezach (Rhees, 1970, s. 39) ${ }^{11}$. Odmienną propozycję uniknięcia mentalistycznych wniosków przedstawia Diamond. Choć odrzuca pomysł Rheesa z przestawieniem definiensa i definiendum, to również ona podkreśla, że Wittgensteinowi nie chodziło o żaden proces, w który byłby uwikłany pozajęzykowy podmiot myślący: teza 3.11 mówi, że metodą projekcji jest sposób odwzorowania, a więc sposób użycia znaku zdaniowego jako obrazu zawierającego możliwość sytuacji. Diamond pisze:

Pomyślenie sensu, pomyślenie sytuacji jest tym, co robi myśl, będąc obrazem odwzorowującym sytuację w przestrzeni logicznej. Sens (sytuacja) jest myślany dzięki temu, że jest odwzorowywany. Jeśli znak zdaniowy w zastosowaniu myśli sens, jest on w swoim zastosowaniu myślą, obrazem logicznym i związany jest ze sposobem odwzorowania (Diamond, 2006, s. 155) ${ }^{12}$.

Zatem jeśli w ogóle mamy mówić o podmiocie aktu pomyślenia, to jest nim sama myśl. Co prawda, znak zdaniowy, aby być myślą, wymaga zastosowania, lecz samo zastosowanie nie jest jeszcze pomyśleniem sensu. Zastosowanie jest przygodną czynnością faktycznych podmiotów, tymczasem relacja między myślą a jej sensem jest istotna (TLP, 4.03). Biorąc zaś pod uwagę, że każdy stosunek istotny jest dla Wittgensteina stosunkiem wewnętrznym - na co wskazuje McGinn, (2006, s. 85) - nie sposób ujmować myśli w oderwaniu od tego, o czym ona jest, a także niepodobna ujmować faktów w oderwaniu od ich wewnętrznych związków z myślami. Stosunek odwzorowania, o którym mowa w tezach 2.15-2.22, nie może być traktowany jako podstawa tych związków, lecz przeciwnie - jako relacja na nich oparta. Dlatego też przyporządkowanie zachodzące między elementami obrazu a ich znaczeniem, o którym mowa w tezie 2.1514 , nie jest zewnętrzne względem samego obrazu, gdyż ustanawiane jest ono dzięki regułom projekcji wynikającym z całego systemu obrazów, czyli z symbolizmu

11 Rhees skorzystał z faktu, że oryginalne niemieckie sformułowanie tezy jest w tej kwestii niejednoznaczne. Argumentację tę powtórzył m.in. Peter Winch (1994, s. 101).

12 Zob. również szersze omówienie tego zagadnienia przedstawione przez Piotra Dehnela (2014, s. 157-163). 
(McGinn, 2006, s. 92 i n.). Jest to zdaniem McGinn konsekwencja Fregowskiej zasady kontekstowości (przywołanej explicite w tezie 3.314). Ostatecznie więc w perspektywie wyznaczonej przez prezentowane wykładnie funkcję łączenia znaków językowych $\mathrm{z}$ ich znaczeniem, wykonywaną w ramach teorii mentalistycznych przez zewnętrzny względem języka podmiot myślący, wedle wczesnego Wittgensteina wykonuje sam symbolizm.

Interpretacja ta może znaleźć wsparcie w tezach 5.6-5.641, podejmujących frapujący wielu komentatorów Traktatu wątek solipsyzmu, rozpoczynający się od znanego stwierdzenia „Granice mego języka oznaczają granice mego świata". Wątek ten jest przede wszystkim krytyką Russellowskiego kartezjanizmu. Zacznijmy jego analizę od tezy 5.633:

Gdzież w świecie da się zauważyć jakiś podmiot metafizyczny?

Powiadasz, że jest to zupełnie jak z okiem i polem widzenia. Ale oka faktycznie nie widzisz.

I nic $w$ polu widzenia nie pozwala wnosić, że jest ono widziane przez jakieś oko.

Występuje tu nawiązanie do argumentacji Russella mającej uzasadnić poznawczy dostęp do ,ja”. Autor The Principles of Mathematics bowiem dowodził, że nasza bezpośrednia znajomość jakiegokolwiek doznania jest w istocie bezpośrednią znajomością dwóch rzeczy: danej zmysłowej, stanowiącej treść tego doznania, oraz podmiotu, który ową daną zmysłową postrzega (Russell, 1995, s. 58). Wittgenstein na przykładzie oka i pola widzenia chce pokazać, że podmiot jako prosty człon relacji, któremu dane są wszystkie akty poznawcze, nie jest nigdy treścią poznania. Nie możemy odnaleźć go w świecie ${ }^{13}$ ani w żaden inny pośredni sposób wprowadzić do języka, a jednocześnie chcielibyśmy o nim mówić14 ${ }^{14}$ Stwierdza to wcześniejsza teza 5.631:

13 Sam Russell zdawał się to przeczuwać, gdyż jego uwagi zdradzają niepewność (Russell, 1995, s. 58). Warto zauważyć, że we wcześniejszych tekstach - np. w Knowledge by Acquaintance and Knowledge by Description z 1910 roku - twierdził, że dostęp do ,ja” nie jest bezpośredni (Russell, 1959, s. 211 i n.).

14 Hans Sluga zauważa, że ten pogląd Ludwiga Wittgensteina jest znacznie radykalniejszy niż antykartezjanizm. Nazywa go ,antyobiektywizmem” (Sluga, 1996, s. 327 i n.). 
Nie ma podmiotu myśli i wyobrażeń.

Gdybym pisał księgę „Świat, jakim go zastałem”, to trzeba by w niej powiedzieć także o moim ciele, jakie członki podlegają mojej woli, a jakie nie, itd.; jest to bowiem pewna metoda wydzielania podmiotu, albo raczej pokazania, że w pewnym ważnym sensie żadnego podmiotu nie ma. O nim bowiem jedynie nie mogłoby być w tej księdze mowy.

Brak kartezjańskiego podmiotu metafizycznego nie oznacza jednak, że w księdze „Świat, jakim go zastałem” podmioty w ogóle nie mogą się pojawić. Po pierwsze, nic nie stoi na przeszkodzie, aby księga opisywała faktyczne podmioty występujące jako swoiste ,zbiorniki" wypowiedzi i przekonań sensownych, czyli myśli-faktów powiązanych ze stanami rzeczy stosunkiem wewnętrznym, wynikającym z projekcji (zgodnie z tezą 5.542). Po drugie, subiektywność (moja) pojawia się w tytule księgi, a także wszędzie, gdzie Wittgenstein pisze o ,moim świecie”. W tym sensie podmiot - zgodnie z tezą 5.632 - jest granicą świata. Postaramy się teraz wykazać, że granica ta jest właśnie wewnętrznym biegunem symbolizmu.

Pojęcie granicy pojawia się w Traktacie kilkakrotnie, w tym po raz pierwszy w Przedmowie, gdzie poruszany jest temat wytyczania granic myślenia poprzez wyznaczenie granic wyrazu myśli (TLP, s. 3). Nie chodzi w żadnym razie o działalność polegającą na podziale pewnego uniwersum na dwie części, z których jedna zostanie uznana za zewnętrzną względem języka - tego nie możemy zrobić, podobnie jak nie możemy zobaczyć granic pola widzenia (Stern 1995, s. 76 i n.) - lecz na rozjaśnianiu logicznej struktury symbolu, a co za tym idzie, na ukazywaniu tego, co da się jasno powiedzieć. Niejako ubocznym skutkiem takiej działalności będzie obnażenie niedorzeczności pozornie poprawnych niby-zdań (McGinn, 2006, s. 18; Dehnel 2014, s. 198). Teza 5.5561 precyzuje, że możliwości ekspresji języka wyznaczane są przez ogół zdań elementarnych, który z kolei wyznaczany jest przez ogół przedmiotów ${ }^{15}$. Granicy języka nie należy więc rozumieć przestrzennie - należy ona do istoty symbolizmu.

Czy pojęcie granicy z Przedmowy można skojarzyć z pojęciem występującym w tezie 5.6? Wyraźnie sugeruje to pierwszy bezpośredni komentarz do tej tezy, a mianowicie teza 5.61:

15 Marie McGinn - za Peterem Sullivanem - wskazuje, że wbrew interpretacjom ontologizującym nie było intencją Wittgensteina stawiać językowi ograniczenia ze względu na empiryczną strukturę rzeczywistości (McGinn, 2006, s. 159 i n.). 
Logika wypełnia świat; granice świata są też jej granicami.

W logice nie można zatem powiedzieć: to a to w świecie jest, a tamtego nie ma.

Znaczyłoby to bowiem na pozór, że wykluczamy pewne możliwości; a tak nie może być, gdyż inaczej logika musiałaby wyjść poza granice świata; musiałaby móc spojrzeć na nie także z drugiej strony.

Czego nie możemy pomyśleć, tego pomyśleć nie możemy; a więc nie możemy też powiedzieć, czego nie możemy pomyśleć.

„Mój świat” i „,mój język” to zatem nie tyle „świat, jakim go zastałem”, który mogę opisać w księdze o takim tytule. To raczej przestrzeń możliwości sensu, a więc przestrzeń logiczna.

Do tak zarysowanej granicy nie da się, rzecz jasna, w żaden sposób bezpośrednio odnosić w języku dopuszczalnym przez Traktat - nie może mieć ona żadnej „legalnej” nazwy: nie jest ani rzeczą prostą, ani kompleksem (nie może być również znaczeniem żadnego z pojęć formalnych, o których mówią tezy 4.126-4.1274). Dlatego też gdy odczytujemy tezy Wittgensteina o granicy jako zdania, uzyskujemy niedorzeczności. Zdaje się temu przeczyć teza 5.641, która mówi:

Jest więc rzeczywiście pewien sens, w jakim można mówić w filozofii o Ja niepsychologicznie.

Ja pojawia się w filozofii przez to, że „świat jest moim światem”.

Ja filozoficzne to nie jest ani człowiek, ani ludzkie ciało, ani ludzka dusza, którą zajmuje się psychologia - lecz podmiot metafizyczny: granica, nie część świata.

Jednak według przyjętej w niniejszym artykule perspektywy właściwym celem filozofii Wittgensteina nie jest prezentowanie teorii, a więc pewnych tez, lecz jasność tez, którą osiąga się dzięki objaśnieniom. Teza 5.641 streszcza cały wątek solipsystyczny i sugeruje, że stanowi on zbiór objaśnień, w jaki sposób można mówić o podmiocie metafizycznym - a ściślej rzecz biorąc, w jaki sposób nie można o nim mówić - wówczas takie objaśnienia mogą mieć pewien sens, gdyż ,przedmiotem”, o jakim w nich mowa, jest niby-pojęcie, ,podmiot”, które próbujemy stosować w naszych wypowiedziach. Podawanie takich filozoficznych objaśnień, biorąc pod uwagę metaforę „granicy świata”, ma na celu wyzwolenie nas od pokusy 
poszukiwania podmiotu metafizycznego jako pewnego przedmiotu możliwego opisu. Jeśli podmiot ten jest granicą świata, to jest on również granicą języka; jak podkreśla teza 5.62, jest to jedyny język, jaki potrafię zrozumieć, nie ma sensu zatem poszukiwać innego języka, w którym można by jakoś inaczej (dokładniej, bardziej przedmiotowo) określić „,miejsce” metafizycznej subiektywności w stosunku do przestrzeni dyskursu, a zarazem tego, co nazywamy rzeczywistością. Takim językiem wyższego rzędu musielibyśmy bowiem niejako od zewnątrz opisywać wzajemne relacje świata, języka i logiki, a niemożliwość tego ruchu jest jednym z fundamentalnych założeń Traktatu ${ }^{16}$.

$\mathrm{Z}$ analiz tych wynika zatem, że podmiot metafizyczny - ten, do którego odnoszą się zaimki dzierżawcze z tez 5.6, 5.62 i 5.63 - nie może być przedmiotem opisu, jest więc nie do pomyślenia. Nie jestem nim zatem ja w tym sensie, w jakim jestem faktycznym podmiotem egzystującym w świecie, posiadającym przekonania i stosującym znaki zdaniowe, ponieważ jako taki jestem opisywalny i dający się pomyśleć. Nieopisywalne „ja”, podmiot myśli i wyobrażeń, jest ujmowane metaforycznie raz jako swój własny świat (mikrokosmos), a innym razem jako granica tego świata (TLP, 5.63-5.632). W niniejszym artykule proponujemy metaforę bieguna ze względu na tradycyjną wykładnię intencjonalności. Wizja mentalistyczna zakłada bowiem, że myśli, a więc akty intencjonalne, rozpięte są między dwoma biegunami, z których jeden jest ich znaczeniem, a drugi podmiotem myślącym. Mentalizm wypełnia więc schemat myślący - myśl - myślane obiektywnym umysłem, wyrażeniami ,,języka myśli' ${ }^{17}$ i obiektywną rzeczywistością. Tymczasem dla autora Traktatu schemat ten jest niczym innym jak wiodącym na manowce rzutowaniem wewnętrznej struktury symbolu na rzeczywistość pozajęzykową. O tym też mówi Wittgenstein w wątku solipsystycznym, który wprowadza bezpośrednio teza 5.62, komentująca stwierdzenie o granicy języka i granicy świata:

16 Próba mówienia tego rodzaju językiem wymagałaby zajęcia perspektywy, z której możliwy byłby - używając sformułowania Johna McDowella - ,widok z boku”, a taka perspektywa nie istnieje (McDowell, 2009, s. 62). Co prawda, McDowell użył tej metafory w odniesieniu do krytyki platonizmu prowadzonej przez późnego Wittgensteina, jednak - jak wskazuje Diamond - również teoria języka wczesnego Wittgensteina wyklucza perspektywę ,widoku z boku” (Diamond, 1991, s. 184 i n.). Pisze o tym także Dehnel, 2014, s. 28 i n.

17 Jest to określenie związane ze znaną hipotezą Jerry’ego Fodora (1975). 
Ta uwaga daje klucz do kwestii, jak dalece solipsyzm jest prawdą.

To bowiem, co solipsyzm ma na myśli, jest całkiem słuszne, tylko nie da się tego powiedzieć: to się widzi.

To, że świat jest moim światem, uwidacznia się w tym, że granice języka (jedynego języka, jaki rozumiem) oznaczają granice mego świata.

Symbolizm Traktatu do projektowania swego sensu nie potrzebuje zatem umysłu w sensie kartezjańskim. Nie potrzebuje również umysłu w sensie transcendentalnym, gdyż to on sam spełnia jego funkcje ${ }^{18}$. Wszystko, co symbolizm jest w stanie przedstawić - całą przestrzeń naszego możliwego doświadczenia - jest ujmowalne z jednoczącej perspektywy transcendentalnej logiki, jedynego a priori obecnego w całości w każdym możliwym symbolu. A skoro nie może być wielu logik, nie może być też wielu wewnętrznych wobec symbolizmu biegunów podmiotowości - dlatego to, co solipsyzm ma na myśli, jest słuszne, przy czym nie da się wypowiedzieć, bo - ściśle rzecz biorąc - nie można mówić o wewnętrznej strukturze symbolu. Jeśli więc wedle interpretacji antymetafizycznej filozofia symbolizmu Traktatu zajmuje miejsce ontologii, używając języka tej ostatniej do budowy objaśnień relacji treści, struktury i formy symbolu, to w prezentowanym tu odczytaniu zajmuje również miejsce filozofii umysłu. Diamond, która jest chyba najbliższa tego wniosku, bezpośrednio go nie formułuje. Jednak jej uwaga, że zastosowany

18 Wielu autorów sugeruje, że wczesny Wittgenstein proponuje pewną wersję zradykalizowanego transcendentalizmu. Przykładowo Sluga twierdzi, że antyobiektywistyczna teoria subiektywności wyłożona w komentowanych tu tezach Traktatu głosi, że podmiot metafizyczny jest „nieobiektywnym warunkiem możliwości obiektywnego świata” (Sluga, 1996, s. 329). Zdaniem Slugi koncepcja ta ma jedną zasadniczą wadę: relacja między podmiotem życia codziennego a podmiotem metafizycznym pozostaje całkowicie nieokreślona. Niemożliwość indywiduacji tego ostatniego prowadzi do wniosku, że nie można mówić o wielości podmiotów. A zatem, twierdzi interpretator, należy określić tę propozycję mianem transcendentalnego solipsyzmu (Sluga, 1996, s. 330). Pojęcia transcendentalnego solipsyzmu w odniesieniu do idei Wittgensteina używa również Hacker, wskazując na nieprzypadkowy charakter związku między światem a subiektywnością i w konsekwencji również na nieprzedmiotowy charakter tej ostatniej (Hacker, 1972, s. 79 i n.). Podobną transcendentalną strukturę tropi w Traktacie także Richard Brockhaus (1991, s. 291 i n.). 
symbol myśli sam siebie, wydaje się sugerować właśnie takie rozumienie koncepcji solipsyzmu (Diamond, 2006, s. 155) ${ }^{19}$.

Może się wydawać, że zaprezentowana tu wykładnia jest zbyt dziwaczna, by odpowiadała rzeczywistym intencjom autora Traktatu. Należy jednak zwrócić uwagę na dwie kwestie. Po pierwsze, upodmiotowienie symbolizmu, to jest uczynienie go odpowiedzialnym za własne znaczenie, nie jest czymś, czemu nie można by przypisać historycznego źródła. Takim źródłem mogła być - najprawdopodobniej znana młodemu Wittgensteinowi - idea myśli jako obiektywnych, a zarazem niematerialnych bytów, należących do „trzeciego królestwa” Gottloba Fregego ${ }^{20}$. Co prawda, Frege zakładał istnienie umysłów będących w stanie odnosić się do rzeczywistości, jednak owo odnoszenie się jest według niego zapośredniczone w myślach. Innymi słowy, potrafimy myśleć i mówić o świecie zewnętrznym tylko dlatego, że potrafimy ujmować myśli - bez nich bylibyśmy skazani wyłącznie na nieintencjonalne doznania (Frege, 1977). Jeśli więc myśli mają być całkowicie niezależne od podmiotów, a zarazem mają zdolność odnoszenia się do przedmiotów w obiektywnym świecie, to należy stwierdzić, że to one - a nie umysły ludzkie - stanowią w teorii Fregego pierwotne źródło intencjonalności. Zatem wedle bronionej tutaj wykładni roli symbolizmu stanowisko Wittgensteina może być postrzegane jako nieco odmienne rozwinięcie idei niemieckiego logika.

Po drugie, przekazanie symbolizmowi funkcji podmiotowości transcendentalnej jest ruchem z punktu widzenia teoretycznych potrzeb wczesnego

19 Nieco tylko podobne odczytanie do wyłożonego w niniejszym artykule zaprezentował niegdyś Jaakko Hintikka, który utożsamił podmiot metafizyczny z ogółem zdań, opierając się na treści tezy 5.542 (Hintikka, 1966, s. 159 i n.). W rozumieniu Hintikki podmiot ten byłby więc złożony, co jest niezgodne $\mathrm{z}$ prezentowaną tu interpretacją Traktatu, wedle której złożone mogą być wyłącznie faktyczne podmioty (przedmioty badań psychologii). McGinn pisze z kolei, że podmiot jako granica świata jest ,,po prostu korelatem reprezentacji świata w zdaniach" (McGinn, 2006, s. 276). W swej analizie dochodzi ona do wniosku, że nie jest to podmiot pierwszoosobowy, ponieważ mamy zdolność przypisywania takiego rodzaju podmiotowości również innym (McGinn, 2006, s. 275). Także ona nie dopowiada jednak, że subiektywność w sensie niepsychologicznym jest biegunem wewnętrznej struktury symbolu.

20 O tym, że Wittgenstein - dzięki rozmowom, jakie odbył z Fregem podczas kilku spotkań w latach 1911-1913 - zapoznał się z pewnymi koncepcjami, które ten ostatni zawarł dopiero w swoim znanym artykule z 1918 roku, pisze np. Michael Potter (2008, s. 262). 
Wittgensteina całkowicie zrozumiałym. Żaden element ,świata, jakim go zastałem" - zarysowanego już w niezwykle cenionych przez filozofa $Z a$ sadach mechaniki Hertza - składającego się ze stanów rzeczy złożonych z przedmiotów prostych, nie nadaje się do roli pierwotnego źródła znaczenia. $\mathrm{Z}$ pewnością roli tej nie są w stanie unieść faktyczne podmioty, o których mowa w tezie 5.542. Rzeczywistość opisywana zdaniami sensownymi jest bowiem domeną przypadku, wszystkie związki w niej zachodzące są akcydentalne (TLP, 6.3) i żaden $\mathrm{z}$ nich nie ma charakteru normatywnego ${ }^{21}$. Tymczasem relacja między zdaniem a jego znaczeniem implikuje normę - wymaga więc instancji, która tę normę usankcjonuje. Wittgenstein opiera się pokusie uznania pozaświatowego charakteru tej instancji i uznaje ją za wewnętrzną względem języka - być może wiedziony tą samą intuicją, którą rozwinął później w Niebieskim zeszycie, krytykując ideę cienia jako obrazu rozumianego bez interpretacji (Wittgenstein, 1998, s. 70 i n.). Nie jest bowiem żadnym rozwiązaniem usuwanie problematycznego elementu poza obręb znanego świata. Stwarza to jedynie dodatkowy problem: w jaki sposób czynnik pozaświatowy ingeruje w naszą rzeczywistość?

\section{Bibliografia}

Anscombe, G.E.M. (1965). An Introduction to Wittgenstein's Tractatus. New York: Harper \& Row.

Black, M. (1964). A Companion to Wittgenstein's Tractatus. Cambridge: Cambridge University Press.

Brockhaus, R.R. (1991). Pulling up the Ladder. The Metaphysical Roots of Wittgenstein's Tractatus logico-philosophicus. La Salle (IL): Open Court.

Crary, A., Read, R. (2009). Wittgenstein - nowe spojrzenie. Wrocław: WN DSW.

Conant, J. (1992). The Search for Logically Alien Thought: Descartes, Kant, Frege, and the Tractatus. Philosophical Topics, 20, 1, 115-180.

Dehnel, P. (2014). Ludwig Wittgenstein: teoria a terapia. Od „Traktatu” do „Dociekań filozoficznych” - studia. Warszawa: WN PWN.

Diamond, C. (1991). Throwing Away the Ladder. W: C. Diamond, The Realistic Spirit (s. 179-204). Cambridge (MA): MIT Press.

21 Normatywność, jak sugerują tezy 6.41-6.422, nie znajduje się w świecie. 
Diamond, C. (2006). Peter Winch on the Tractatus and the Unity of Wittgenstein's Philosophy. W: A. Pichler, S. Säätelä (eds.), Wittgenstein: The Philosopher and his Works (s. 141-171). Frankfurt: Ontos.

Diamond, C. (2009). Etyka, wyobraźnia i metoda Traktatu Wittgensteina. W: A. Crary, R. Read (red.), Wittgenstein - nowe spojrzenie (s. 181-211). Wrocław: WN DSW.

Fodor, J. (1975). The Language of Thought. Cambridge (MA): Harvard University Press.

Frege, G. (1977). Myśl. Studium logiczne. W: G. Frege, Pisma semantyczne (s. 101-129). Warszawa: PWN.

Goldfarb, W. (2011). Das Überwinden. Anti-Metaphysical Readings of the Tractatus. W: R. Read, M.A. Lavery (eds.), Beyond the Tractatus Wars. The New Wittgenstein Debate (s. 6-21). New York: Roudledge.

Hacker, P. (1972). Insight and Illusion: Wittgenstein on Philosophy and the Metaphysics of Experience. Oxford: Oxford University Press.

Heflik, W. (2013). Problem formy w perspektywie transcendentalnej u Kanta i Wittgensteina. Analiza porównawcza na podstawie „Krytyki czystego rozumu” $i$,,Traktatu logiczno-filozoficznego”. Kraków: Antykwa.

Hintikka, J. (1966). On Wittgenstein's „Solipsism”. W: I. Copi, R. Beard (eds.), Essays on Wittgenstein's Tractatus (s. 157-161). New York: Macmillan.

Hutto, D. (2003). Wittgenstein and the End of Philosophy. Neither Theory nor Therapy. Basingstoke-New York: Palgrave Macmillan.

Ishiguro, H. (1969). Use and Reference of Names. W: P. Winch (ed.), Studies in the Philosophy of Wittgenstein (s. 20-51). London: Routledge.

Malcolm, N. (1994). Wittgenstein: A Religious Point of View?, Ithaca: Cornell University Press.

McDowell, J. (2009). Nonkognitywizm i postępowanie według reguły. W: A. Crary, R. Read (red.), Wittgenstein - nowe spojrzenie (s. 55-72). Wrocław: Wydawnictwo Naukowe Dolnośląskiej Szkoły Wyższej.

McGinn, M. (1999). Between Metaphysics and Nonsense: Elucidation in Wittgenstein's Tractatus. The Philosophical Quarterly, 49, 197, 491-513.

McGinn, M. (2006). Elucidating the Tractatus. Wittgensten's Early Philosophy of Logic and Language. Oxford: Oxford University Press.

Moyal-Sharrock, D. (2007). The Good Sense of Nonsense: a reading of Wittgenstein's Tractatus as nonself-repudiating. Philosophy, 82, 1, 147-177. 
Pears, D. (1987). The False Prison: A Study of the Development of Wittgenstein's Philosophy. T. I. New York: Clarendon Press.

Potter, M. (2008). Wittgenstein's Notes on Logic. Oxford: Oxford University Press.

Rhees, R. (1970). Discussions of Wittgenstein. London: Routledge \& Kegan Paul.

Russell, B. (1959). Mysticism and Logic and Other Essays. London: Allen \& Unwin.

Russell, B. (1995). Problemy filozofii. Warszawa: PWN.

Sluga, H. (1996). „Whose house is that?” Wittgenstein on the self. W: H. Sluga, D. Stern (eds.), The Cambridge Companion to Wittgenstein (s. 320-353). Cambridge: Cambridge University Press.

Stenius, E. (1960). Wittgenstein's Tractatus. A Critical Exposition of Its Main Lines of Thought. Ithaca: Cornell University Press.

Stern, D. (1995). Wittgenstein on Mind and Language. Oxford: Oxford University Press.

Walentukiewicz, W. (1998). Definicje deiktyczne w Traktacie. W: M. Soin (red.), Wittgenstein w Polsce (s. 21-61). Warszawa: IFiS PAN.

Winch, P.G. (1994). Discussion of Malcolm's Essay. W: N. Malcolm, Wittgenstein: A Religious Point of View? (s. 95-135). Ithaca (NY): Cornell University Press.

Wittgenstein, L. (1997). Tractatus logico-philosophicus. Warszawa: WN PWN.

Wittgenstein, L. (1998). Niebieski zeszyt. W: L. Wittgenstein, Niebieski i brązowy zeszyt. Szkice do Dociekań filozoficznych (s. 21-123). Warszawa: Spacja.

\section{SUBJECT AS THE INNER POLE OF THE SYMBOL. ANTI-MENTALISTIC INTERPRETATION OF WITTGENSTEIN'S TRACTATUS}

\section{Summary}

The purpose of this paper is to offer a radical anti-mentalistic interpretation of Wittgenstein's Tractatus. Contrary to mentalistic approaches postulating that the task of projection must be performed by a subject (transcendental or psychological), the author claims - after Rhees, Diamond and McGinn - that the projection itself is an intrinsic relation within the symbol. The main point of the paper is the thesis 
that the transcendenal subjectivity - or, as Wittgenstein calls it, the metaphysical subject - is the inner pole of the symbol, and since the meaning of the symbol is it's other inner pole (as anti-realist interpretations point out), the whole intentional relation of symbolizing is intrinsic to the symbolism. 